\title{
Case report. Bijzonder recidief in de nier van een primair oesofaguscarcinoom
}

\author{
Tamara J. Oderkerk' ${ }^{1}$ Wouter M. H. Van der Sanden ${ }^{1}$ ' Laurent M. C. L. Fossion ${ }^{1}$
}

Published online: 18 May 2018

() The Author(s) 2018

\section{Samenvatting}

We presenteren een bijzondere casus van een recidief/metastase in de nier van een primair oesofaguscarcinoom.

Trefwoorden tumorrecidief $\cdot$ oesofaguscarcinoom $\cdot$ renaalcelcarcinoom $\cdot$ metastase

\section{Case report. A surprising renal involvement as tumor recurrence of a primary esophageal carcinoma}

\begin{abstract}
We present a case of a surprising renal involvement as tumor recurrence of a primary esophageal carcinoma.
\end{abstract}

Keywords tumor recurrence $\cdot$ esophageal carcinoma $\cdot$ renal cell carcinoma $\cdot$ metastasis

\section{Introductie}

Kanker van de oesofagus treft meer dan 450.000 personen wereldwijd en de incidentie neemt snel toe. Het is een van de meest dodelijke kankersoorten, mede door het agressieve karakter ervan [1].

In retrospectieve studies over oesofaguscarcinoom blijken roken, het drinken van hete thee, het consumeren van rood vlees, een slechte mondhygiëne, een lage inname van vers(e) groenten en fruit en een lage sociaal-economische status geassocieerd te zijn met een hoger risico op oesofageaal plaveiselcelcarcinoom. Barrett-oesofagus wordt duidelijk herkend als een risicofactor. In de klinische praktijk is dysplasie van de slokdarm de enige factor van betekenis voor het detecteren van patiënten met een verhoogd risico op het ontwikkelen van een oesofageaal adenocarcinoom [1].

Chirurgische resectie blijft de primaire behandelmethode. Slechts bij een klein aantal patiënten is de resectie curatief en is er een kans op langdurige overleving. 19-64\% van de patiënten komt in aanmerking voor een curatieve

Tamara J. Oderkerk

tamaraoderkerk@gmail.com

1 afdeling urologie, Máxima Medisch Centrum Veldhoven,

Veldhoven, Nederland resectie van de oesofagus met een vijfjaarsoverleving die varieert van $10-55 \%$, afhankelijk van het stadium [2].

Een Franse studie laat zien dat het oesofaguscarcinoom gemiddeld 17,8 maanden na de operatie terugkeert en dat $45,7 \%$ van alle recidieven gevonden wordt binnen 12 maanden na de operatie. Deze studie heeft ook de voorspellende factoren voor het recidiverende karakter van de ziekte onderzocht. Of iemand een recidief krijgt, blijkt vooral afhankelijk van de invasiediepte van de tumor. Patiënten met een pT3-tumor hebben de slechtste prognose (63\% recidief) [2].

Een oesofaguscarcinoom dat infiltreert in het omliggende weefsel groeit in de meeste gevallen door tot in het mediastinum, door de trachea heen. Van daaruit migreren de tumorcellen naar de lever en de longen. Lymfogene verspreiding kan leiden tot metastasen in de bovenbuik, het mediastinum en de cervicale wervels [3].

We presenteren een zeldzaam geval van een recidief oesofaguscarcinoom in de nier. In de literatuur zijn slechts enkele soortgelijke case reports beschreven [4-7]. In de meeste gevallen is aan de patiënten chemotherapie voorgesteld. Deze aanpak was echter niet succesvol. 


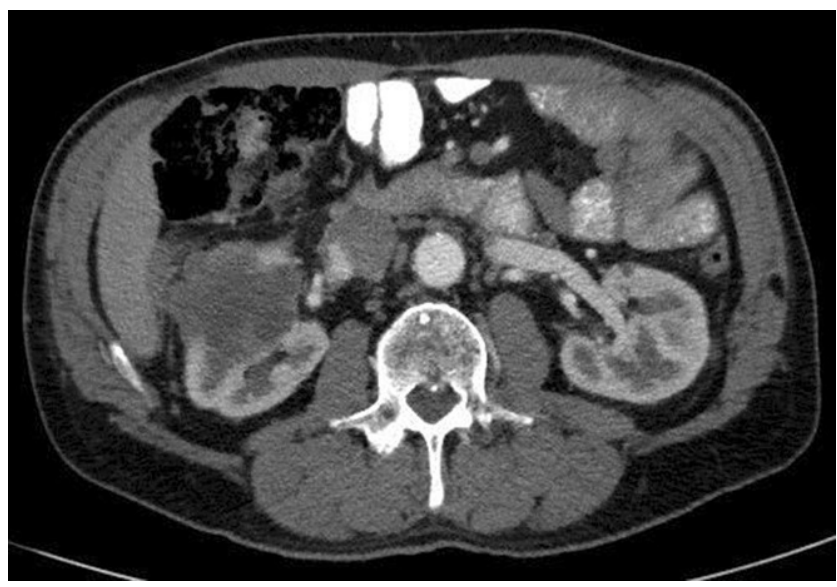

Figuur 1 Een transversale afbeelding van het abdomen, een massa van $70 \mathrm{~mm}$ in de bovenste kwadrant van de rechternier

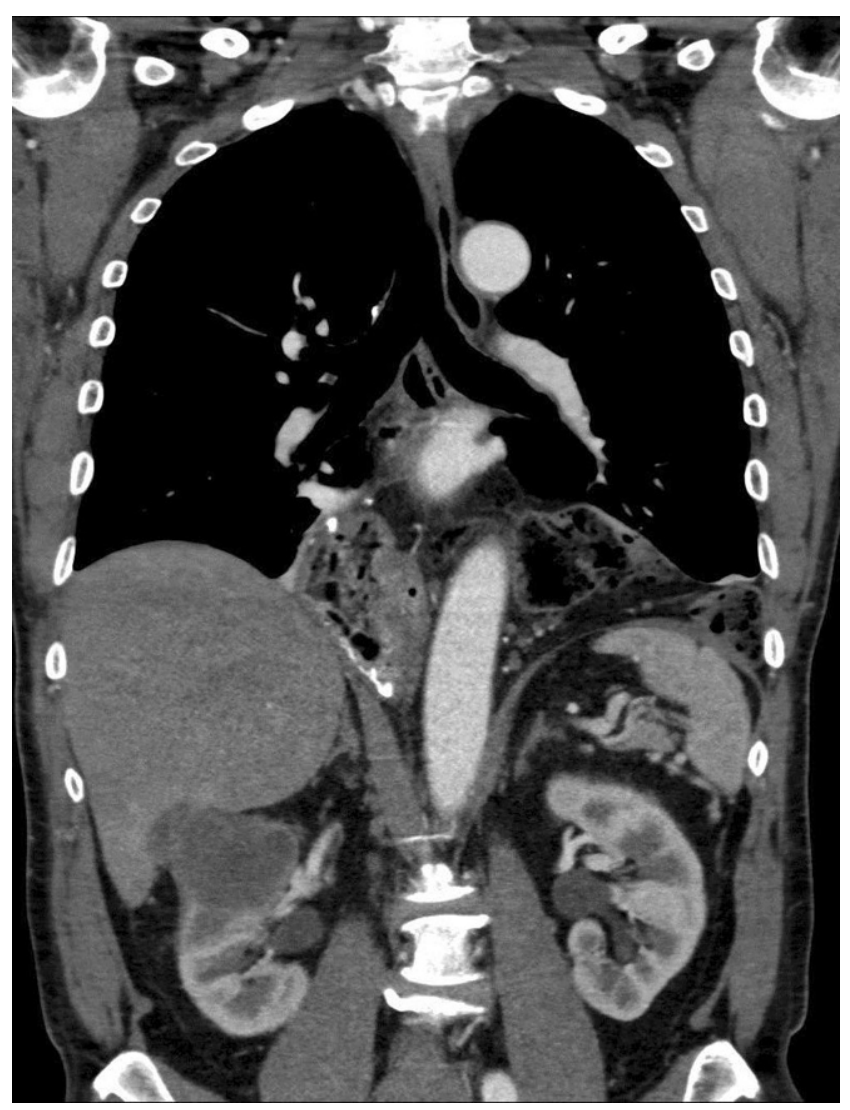

Figuur 2 Een coronaire afbeelding van het abdomen, een solide massa van de rechternier met betrokkenheid van de fascie van Gerota en hoogst waarschijnlijk ook doorgroei in de lever

\section{Casus}

Een 65-jarige man presenteerde zich op de polikliniek Urologie met intermitterende hematurie en rugpijn. De patiënt was bekend met pT3N0-plaveiselcelcarcinoom van de oesofagus, waarvoor hij twee jaar eerder behandeld was met neoadjuvante chemoradiatie, gevolgd door een thoracolapa- roscopische oesofagusresectie met buismaagreconstructie. De patiënt rookte sigaretten.

Diagnostiek met behulp van een echo onthulde een solide massa in de rechternier, met een maximumdiameter van $4,8 \mathrm{~cm}$, dichtbij de lever. Op de CT-scan van de thorax en het abdomen werd een grote massa van $7 \mathrm{~cm}$ gezien in het bovenste kwadrant van de rechternier. Verder werd betrokkenheid van de fascie van Gerota gezien, met waarschijnlijke infiltratie van de tumor in de lever (fig. 1 en 2).

De patiënt werd besproken tijdens het multidisciplinair oncologische overleg, waarin werd geconcludeerd dat de patiënt in aanmerking kwam voor een radicale nefrectomie, omdat er geen andere metastase of abnormaliteiten waren gediagnosticeerd. Hij onderging een laparoscopische nefrectomie van zijn rechternier. Tijdens de operatie bleek sprake te zijn van tumorinvasie in de lever. Ook waren er 10 verdachte paracavale klieren aanwezig. Deze zijn verwijderd door middel van een laparoscopische paracavale lymfeklierdissectie. De nier werd veilig gereseceerd en ingestuurd naar de patholoog. Pathologische wees uit dat er een plaveiselcelcarcinoom was met een maximumdiameter van $7 \mathrm{~cm}$ en diffuus abnormaal weefsel van de lever, met plaveiselcellen. Ook in een van de verwijderde paracavale lymfeklieren werd een metastase gevonden. Het stadium van de ziekte werd gesteld op een pTxN1M2-plaveiselcelcarcinoom van de oesofagus.

Verdere behandeling werd vervolgd in een ander ziekenhuis met specialisatie in oesofaguscarcinomen. Nieuw stadiëringsonderzoek twee maanden na de nefrectomie liet geen andere metastasen zien. De follow-up wordt voortgezet.

\section{Discussie}

We presenteren een zeldzame manifestatie van een laattijdig recidief in de rechternier, twee jaar na de behandeling voor een primair oesofaguscarcinoom.

De resultaten van de Franse studie suggereren dat patiënten die een hoog risico hebben op recidief moeten worden geïdentificeerd in het preoperatieve stadiëringsproces. In deze studie vond meer dan $50 \%$ van alle recidieven binnen 12 maanden na de operatie plaats: lokaal, regionaal of op afstand [2].

\section{Primair renaalcelcarcinoom}

Renaalcelcarcinoom (RCC) had in 2012 een incidentie van 84.000 in de Europese Unie, en een mortaliteit van 35.000 [8]. De vijfjaarsoverleving is in de laatste 50 jaar verdubbeld, van $34 \%$ in 1954 naar $73 \%$ in de periode 2005-2011 [9]. 
De meeste patiënten presenteren zich met klachten van hematurie of pijn, of worden gediagnosticeerd na een toevalsbevinding van een massa in de nier [10]. Meestal wordt de diagnose RCC gesteld met behulp van echografie of CT en soms met behulp van MRI. De definitieve diagnose wordt meestal gesteld op grond van weefselonderzoek na (partiële) nefrectomie.

Vanwege de hoge diagnostische nauwkeurigheid van het CT-abdomen wordt een biopt van de nier niet geadviseerd indien de beeldvorming een verdachte solide afwijking van de nier laat zien en de patiënt in aanmerking komt voor een chirurgische resectie [11].

Als curatieve behandeling heeft chirurgie de voorkeur bij patiënten met RCC stadium I, II en III, zonder metastasen. Chirurgie bestaat uit een radicale of partiële nefrectomie, afhankelijk van de afmeting en lokalisatie van de tumor. Er is geen bewezen effect van adjuvante radiotherapie [11, 12].

\section{Metastasen naar de nier}

De primaire tumoren die het vaakst metastaseren naar de nier zijn melanomen en solide tumoren, voornamelijk longen mammacarcinomen, maar ook maag-, pancreas-, darmen gynaecologische tumoren [10, 13].

\section{Andere behandelopties?}

Chirurgie gevolgd door adjuvante chemotherapie is een veel gebruikte benadering bij de behandeling van solide tumoren. Zou het verschil hebben gemaakt als de patiënt na de resectie van zijn oesofaguscarcinoom adjuvante chemotherapie zou hebben gehad? Adjuvante chemotherapie bij oesofaguscarcinomen is nog niet uitgebreid bestudeerd. Wel toont een gerandomiseerde trial aan dat adjuvante chemotherapie na een oesofagusresectie bij oesofaguscarcinoom niet leidt tot een langere overleving en dat deze behandeling de kans op recidieven niet vermindert [8, 14].

\section{Conclusie}

Een patiënt presenteerde zich met een CT-beeld van een solitaire solide afwijking in de nier. Omdat bij beeldvorming geen andere metastasen werden gevonden, werd besloten tot een radicale nefrectomie, zonder eerst een preoperatief biopt te nemen. De pathologieresultaten lieten een metastase/recidief van zijn eerdere oesofaguscarcinoom zien. Twee maanden later werden er op een follow-up-CT geen nieuwe afwijkingen gevonden. Patiënt wordt momenteel opgevolgd.

Open Access This article is distributed under the terms of the Creative Commons Attribution 4.0 International License (http:// creativecommons.org/licenses/by/4.0/), which permits unrestricted use, distribution, and reproduction in any medium, provided you give appropriate credit to the original author(s) and the source, provide a link to the Creative Commons license, and indicate if changes were made.

\section{Literatuur}

1. Zhang Y. Epidemiology of esophageal cancer. World J Gastroenterol. 2013;19(34):5598-606.

2. Mariette C, Balon JM, Piessen G, et al. Pattern of recurrence following complete resection of esophageal carcinoma and factors predictive of recurrent disease. Cancer. 2003;97(7):1616-23.

3. Jaconsen A, Stoldt S. Metastatic patterns of esophageal cancer. Oncolex, Oncology Encyclopedia. 2009. http://oncolex.org/ esophageal-cancer/Background/MetastaticPatterns. Geraadpleegd op: 3 jul 2017.

4. Díaz de Liaño A, Moras N, Ciga MA, et al. Simultaneous presentation of oesophageal and renal cancer. Clin Transl Oncol. 2007;9(3):195-7.

5. Kitami K, Masuda M, Chiba K, Kumagai H. Metastatic renal tumor originating from esophageal carcinoma: a case report. Hinyokika Kiyo. 1987;33(8):1221-5.

6. Satoh S, Ujiie T, Nomura K, et al. Metastatic renal tumor of esophageal carcinoma: report of a case. Hinyokika Kiyo. 1989;35(6):1025-9.

7. Shimizu H, Koyama Y, Ozawa I, et al. An esophageal cancer with a renal metastasis that was detected and resected as the only focus of recurrence. Gan No Rinsho. 1990;36(11):2047-52.

8. Urschel JD, Vasan H. A meta-analysis of randomized controlled trials that compared neoadjuvant chemoradiation and surgery to surgery alone for resectable esophageal cancer. Am J Surg. 2003;185(6):538-43.

9. Pantuck AJ, Zisman A, Belldegrun AS. The changing natural history of renal cell carcinoma. J Urol. 2001;166(5):1611.

10. Tanagho E, McAninch J. Smith's general urology. 7e druk. Pensylvania: McGraw-Hill; 2007.

11. Ljungberg B, Albiges L, Bensalah K, et al. Guidelines on renal cell carcinoma. European association of Urology. 2015.

12. Flanigan RC, Campbell SC, Clark JI, Picken MM. Metastatic renal cell carcinoma. Curr Treat Options Oncol. 2003;4(5):385-90.

13. Novick AC, Jones JS, Gill IS, et al. Operative urology: at the Cleveland Clinic. New York City: Humana Press; 2006.

14. Ando N, Iizuka T, Kakegawa T, et al. A randomized trial of surgery with and without chemotherapy for localized squamous carcinoma of the thoracic esophagus: the Japan Clinical Oncology Group study. J Thorac Cardiovasc Surg. 1997;114:205-9.

Tamara J. Oderkerk coassistent

Wouter M.H. Van der Sanden arts-assistent urologie

Laurent M.C.L. Fossion uroloog 